\title{
Staging the clinically negative neck in T1-T2 oral cancers: USgFNAC and sentinel node biopsy
}

\author{
S Arya ${ }^{*}$, S Datta, P Chaturvedi \\ From International Cancer Imaging Society (ICIS) 14th Annual Teaching Course \\ Heidelberg, Germany. 9-11 October 2014
}

\section{Background}

A meta-analysis by deBondt declared ultrasound guided fine needle aspiration cytology (USgFNAC) as the method with the highest diagnostic odds ratio for detecting metastatic nodes in head and neck squamous carcinoma (HNSCC). Sentinel node biopsy (SNB) is another emerging method for evaluating neck nodes in HNSCC with reported high sensitivity and negative predictive value (NPV).

\section{Objective}

The aim of this study was to compare USgFNAC with SNB for the preoperative evaluation of the clinically negative neck in T1 \& T2 oral cavity squamous cell carcinoma (OCSCC).

\section{Methodology}

This is a prospective observational study in 51 patients with T1-T2 N0 OCSCC. Pre-operative ultrasonography (US) of the neck was performed in all patients. USgFNAC was performed in patients where US was reported as indeterminate or positive. SNB was performed in all patients and was followed by elective neck dissection (END). The sensitivity, specificity, positive predictive value (PPV) and NPV of SNB, USgFNAC and US were calculated considering END and histopathology (HP) as the gold standard.

\section{Results}

The incidence of occult metastasis on HP was $26.4 \%$. The sensitivity, specificity, PPV and NPV were $71.4 \%, 100 \%$, $100 \%$ and $90.2 \%$ for SNB; $50 \%, 82 \%, 50 \%$ and $82 \%$ for US; and $14.3 \%, 100 \%, 100 \%$ and $76.5 \%$ for USgFNAC respectively.

\footnotetext{
* Correspondence: supreeta.arya@gmail.com

Tata Memorial Centre, Mumbai, India
}

(c) 2014 Arya et al; licensee BioMed Central Ltd. This is an Open Access article distributed under the terms of the Creative Commons Attribution License (http://creativecommons.org/licenses/by/4.0), which permits unrestricted use, distribution, and reproduction in any medium, provided the original work is properly cited. The Creative Commons Public Domain Dedication waiver (http://creativecommons.org/publicdomain/zero/1.0/) applies to the data made available in this article, unless otherwise stated.

\section{Conclusions and relevance}

The meta-analysis by deBondt with reported highest accuracy for USgFNAC included both clinically positive and negative necks. This study evaluated USgFNAC and SNB found SNB clearly superior to USgFNAC.

Published: 9 October 2014

doi:10.1186/1470-7330-14-S1-S10

Cite this article as: Arya et al:: Staging the clinically negative neck in T1-

T2 oral cancers: USgFNAC and sentinel node biopsy. Cancer Imaging 2014 14(Suppl 1):S10. in the clinically negative neck in T1-T2 oral cancers and
Submit your next manuscript to BioMed Central and take full advantage of:

- Convenient online submission

- Thorough peer review

- No space constraints or color figure charges

- Immediate publication on acceptance

- Inclusion in PubMed, CAS, Scopus and Google Scholar

- Research which is freely available for redistribution Submit your manuscript at
www.biomedcentral.com/submit C BioMed Central

\section{Biomed Central}

